\title{
山梨県東部の最近の地震活動とその地学的意味
}

\author{
防災科学技術研究所* 野 口伸一 \\ 気象研究所** 吉田 明夫

\section{Recent Seismic Activity in the Eastern Yamanashi Prefecture and Its Tectonic Implications}

\author{
Shin'ichi NoguchI \\ National Research Institute for Earth Science and Disaster Prevention, 3-1, \\ Tennodai, Tsukuba, Ibaraki 305, Japan \\ and Akio Yoshida \\ Meteorological Research Institute, 1-1, Nagamine, Tsukuba, Ibaraki 305, Japan \\ (Received February 12, 1991; Accepted November 7, 1991)
}

\begin{abstract}
Spatial and temporal variations of seismicity in the eastern Yamanashi Prefecture during the period January 1, 1980 through September 30, 1990 are investigated in detail on a basis of precisely determined hypocenters and magnitudes. It is suggested that a fracture boundary exists in the Philippine Sea plate extending from northwest of Manazuru headland toward the mid of the eastern Yamanashi seismic zone. Seismicity in the eastern Yamanashi is high on its west side. In particular most earthquakes in the depth range below $20 \mathrm{~km}$ occur to the west of the extension of the fracture boundary. On the other hand the August 8, 1983 earthquake with an $M 6.0$ and most of its aftershocks occurred on the east side of the fracture at relatively shallow depth around $20 \mathrm{~km}$ distributing along an inclined plane to the north. We consider that the cause of the 1983 earthquake was rebounding of the land plate dragged by the subducting Philippine Sea slab in the east side of the fracture boundary. After the 1983 earthquake noticeable changes in seismicity were observed on the west side of the fracture. There has been recognized a seismic gap in the eastern Yamanashi seismic region. A part of the seismic gap was filled with aftershocks of the September 5, 1988 earthquake with an $M$ 5.6. In the rest of the gap, whose volume is about $3 \times 4 \times 6$ cubic $\mathrm{km}$, seismicity seems to have decreased further since the occurrence of the $M 5.6$ earthquake in 1988 , and it is expected that an $M 5-6$ earthquake will occur in the near future to fill the gap.
\end{abstract}

Key words: Eastern Yamanashi seismic region, Fracture in the Philippine Sea plate, Seismic gap.

\section{$\S 1$. 序}

山梨県東部の地震活動域は, 伊豆半島を八の字型に挟 む駿河・相模両トラフを陸上に延長した接合部付近に位 置しており, 関東・東海地域の地震デー夕に基づくプ レートの研究の中で, ここは, フィリピン海プレート （以下 PHS プレートと略記する）と大陸プレートの衝突 境界にあたると考えられている [例えば, 石橋 (1980), 笠原 (1985a)]. その北西側には, PHS プレートの沈み込

* $\mathbf{7} 305$ 茨城県つくば市天王台 3-1

** $\mathbf{T} 305$ 茨城県つくば市長峰 1-1
みを示す地震がみられないが, 最近, 微小地震の变換波 の観測からこの地域での PHS スラブ上面に相当する之 みられる境界面が調べられている [堀内・他 (1989), 涌 井・北村 (1989), IIDAKA et al. (1990), 飯高 - 他 (1990), 津村 • 他 (1990)].

石橋 (1988a, 1988b) は, 広範囲の観測データから, 衝 突する伊豆地塊と関東下にもぐり込むPHS プレートす なわち関東スラブの間に, PHS プレート内の断裂があ ると考え, 西相模湾断裂説を提唱した. これによれば, 伊豆半島東沖から北北西に走る想定西相模湾断裂の東西 でPHS プレート上面は著しい段差を持ち, 関東スラブ 
はその断裂の所で左横ずれしつつ伊豆地塊の下にもぐり 込んでいる. 山梨県東部の地震活動域は, 西相模湾断裂 境界の西側に位置しており, 箱根火山北方から浮揚性沈 み込みをしている伊豆地塊（伊豆内弧部分）先端での陸 側プレートとの衝突域に相当する.

一方, 吉田 (1990) は, 神奈川県西部の小田原付近か ら北側の山梨県境付近までの約 $30 \mathrm{~km}$ の帯状の地震活 動域に着目し, この地震帯西縁の境界は真鶴岬の北西か ら山梨県東部に直線的に延びていて, かつ震源の垂直断 面分布からその西縁はほとんど鉛直な面とみなせるこ と, この地震帯の南北の地震活動に相関がみられるこ と,さらにこの地震帯西縁を北に延長した所を境に山梨 県東部の地震活動度が東西で著しく異なることなどか ら, この地震帯西縁が PHS プレート内の断裂を現わし ており，この東側の関東スラブは衝突する伊豆地塊に対 して左横ずれしつつ関東平野下に沈み込んでいると考え た.

いずれにせよ，山梨県東部の地震活動域は,これら想 定断裂面の北側延長上付近に位置しており，この断裂を
介して神奈川県西部の大地震, いわゆる小田原地震 [石 橋 (1977), ISHIBASHI (1985), 笠原 (1985 b), 坂田 (1987)] の発生とも関係を持つことが予想される.また, 過去, 山梨県東部域で, 1923 年関東地震 $(M 7.9)$ 前後や 1930 年北伊豆地震 $(M 7.3)$ の後, また 1931 年 6 月の東 京都中部地震 $(M 6.3)$ や 1931 年 9 月の西埼玉地震 $(M$ 6.9) の前に顕著な地震活動があったことが知られており [例えば, 宇津 (1979), 石橋 (1980), 吉田・浜田 (1989), YoshidA and HAMADA (1991)], 山梨県東部の地震活動 と関東周辺での広域の地震活動との関連, 連動性が注目 される.

山梨県東部は, このように関東周辺における地震の相 互関係, 発生樣式を解明する上で要となる活動域であ り，テクトニックな場の一つの敏感点にあたっていると 考えられる.ここでは, 神奈川県西部に想定される PHS プレートの断裂との関連に注意しながら, 山梨県東部活 動域の震源分布の特徴之最近の地震活動の時間変化を詳 しく調べ，それら地震活動の特徴に含まれるテクトニッ クな意義を考察する.

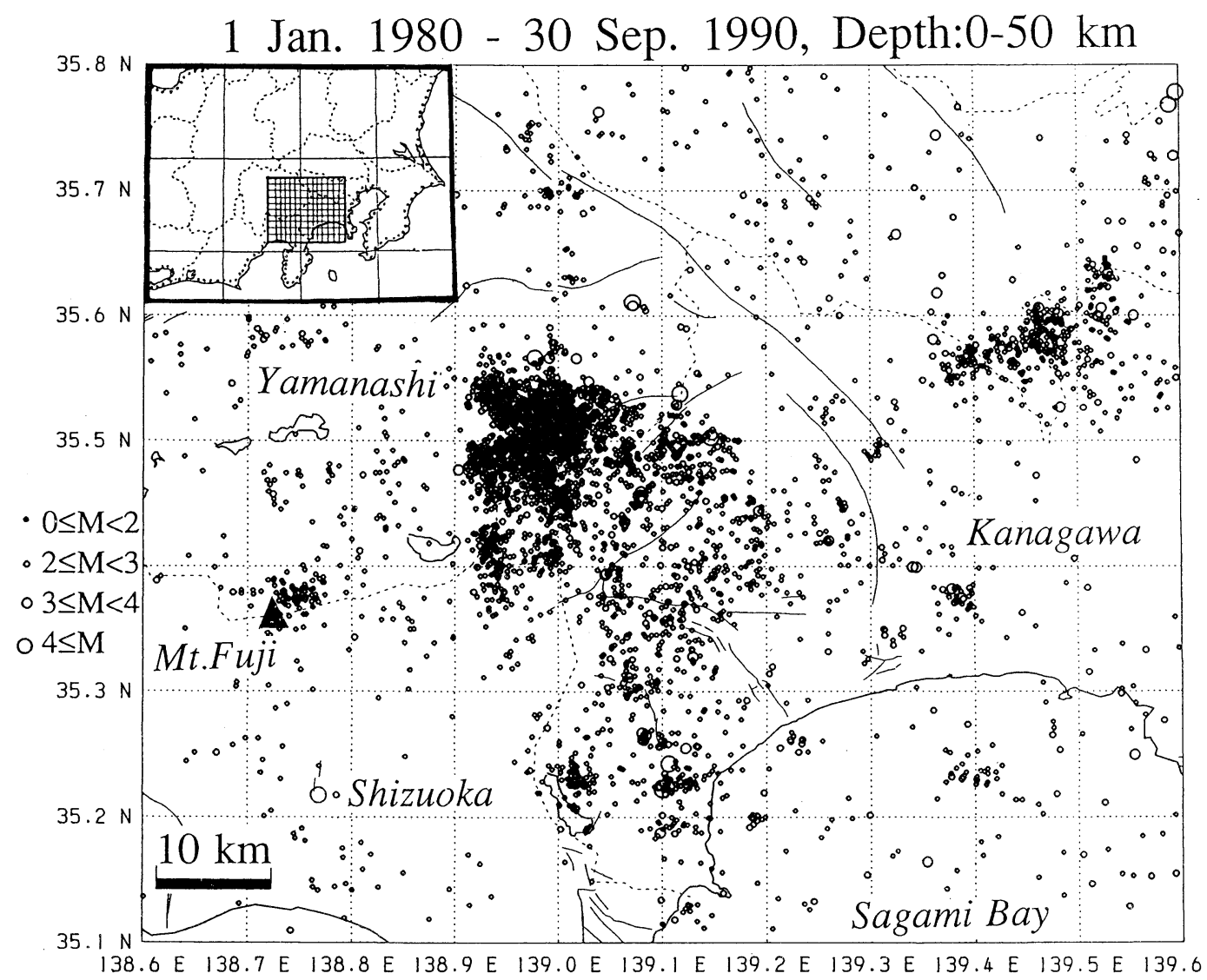

Fig. 1. Epicentral distribution of earthquakes with $M \geqq 0.0$ and depth $50 \mathrm{~km}$ for the period from January 1, 1980 through September 30, 1990. Solid lines are major traces of active faults. 
(a)

1 Jan. 1980 - 30 Sep. 1990, Depth:0-50 km

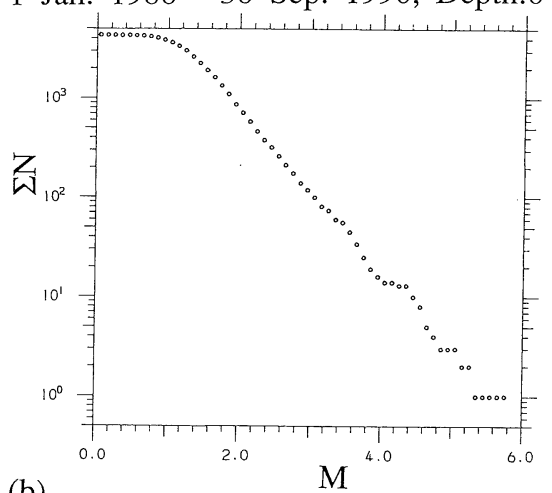

(b)

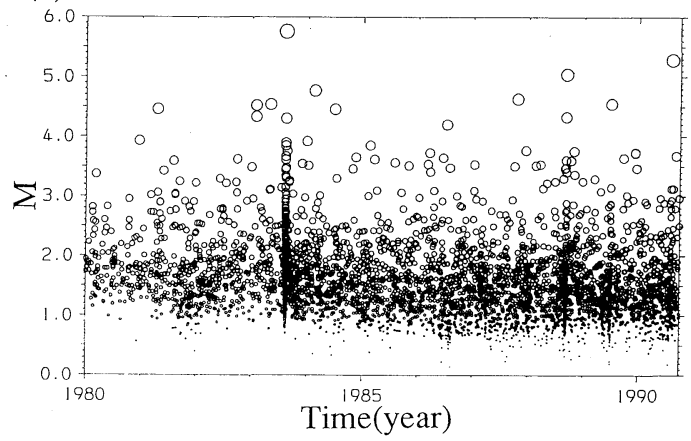

Fig. 2. (a) Magnitude-cumulative frequency distribution, and (b) magnitude-time distribution, for earthquakes shown in Fig. 1.

\section{§ 2. 山梨県東部〜神奈川県西部の震源分布}

Fig. 1 は, 1980 年 1 月〜 1990 年 9 月の期間における 山梨県東部を含む $35.1 \sim 35.8^{\circ} \mathrm{N}, 138.6 \sim 139.6^{\circ} \mathrm{E}$, 深さ 0〜50 km の地震の震央分布である. 山梨県東部の地震 集中域は, 後で示すように丹沢山地西側の都留市〜道志 村直下のほぼ 15〜28 km の深さにある. Fig. 1 の震源 とマグニチュードは，防災科学技術研究所のルーチン処 理デー夕から各観測点での $\mathrm{P}, \mathrm{S}$ 波の走時偏差およびマ グニチュード残差の平均值を求め, 元のデー夕に各々補 正を施して再決定したものを用いている。この地域で は，日中のある時間帯に限って特定地域に震源が求まる 発破と判断されるあのが相当見いだされた。これは既に ルーチン化されている発破デー夕の除去 [松村 (1985)] の条件からはずれるものが最近増えてきたためと考えら れ，新たに地域と時間帯を指定してそれらは除外した。

Fig. 2(a), (b) は, Fig. 1 の地震についてみた $M$ の積算 度数, および $\mathrm{M}-\mathrm{T}$ 分布である. 1984 年 4 月以降は観測 点の配置はほぼ一定となり, 南関東地域での $M \geqq 1.3$ 程度の地震はほとんど漏れなく検出されていると考え られる[例えば, Papanastassiou and Matsumura
(1987)]。しかし，全期間を通した 1980 年以降では， Fig. 2(b) からほぼ $M \geqq 1.5$ について漏れなく観測されて いると推定されるので， 83 における地震活動の時間変 化の解析は $M \geqq 1.5$ について行った。 なお，防災科学技 術研究所の観測網では，地震の規模が大きくなると多く の観測点で最大振幅がスケールアウトする [例えば，野 口 (1990)] ため, Fig. 2 の大きな地震の $M$ は信頼度が低 い. そのため, 以下, $M 5$ 以上の地震の $M$ は気象庁に よっている.

Fig. 3 は, 山梨県東部〜神奈川県西部の地震の震央分 布を深さ $10 〜 20 \mathrm{~km}$ と 20〜30 km に分けて示したも のである. (a) の深さ 10〜20 km の分布には，真鶴岬北 側から丹沢山地にかけて帯状の活動域がみられる. 吉田 (1990) は，この地震帯を “道志一小田原サイスミック ゾーン’ と呼び，その西縁の南端から折れまがりさらに 伊豆半島の丹那断層に続くラインに着目して，そこが PHS プレート内の断裂を表わしていると考えた，以下 では, Fig. 3 に太い破線で示されたこの地震帯の西縁お よびその鉛直下方に想定される境界面を ‘WB' と略記す る. 一方, 石橋 $(1988 \mathrm{a}, \mathrm{b})$ は, 約 $35^{\circ} \mathrm{N}$ の伊東沖から真 鶴岬東側を通って $35.4^{\circ} \mathrm{N}$ 付近にかけて，ほぼ図中の細 い破線を上端の地表投影とする PHS プレート内の断裂 が存在するとして，それを西相模湾断裂（WSBF と略記 する）と名づけた。 “道志一小田原サイスミックン゙ーン’ は，ほぼこのふたつの想定断裂境界にはさまれる，Fig. 3(b) の深さ 20 30 km の震央分布では， 小田原付近の 地震はみられず山梨県東部の地震が顕著である。そし て, その主要な活動域の東縁はWB の北側延長線とほぼ

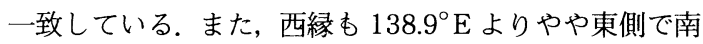
北に明瞭である。なお，これら深さ $10 \sim 30 \mathrm{~km}$ の地震 活動域の西側には火山フロントが走り, WB の南端付近 で交差している.

次に, Fig. 4(a)のような矩形領域について, 震源の鉛 直分布を調べることにする. Fig. 4(b) は, 山梨県東部の 活動域を含む $\mathrm{AA}^{\prime}$ から神奈川県西部にいたる $\mathrm{DD}^{\prime}$ 領域 （各々幅約 $13 \mathrm{~km}$ ）について，WB に直交する断面でみ た震源鉛直分布である．図中中央の破線は; WB 境界面 抢よびこれを北側に延長した線を示す。まず， $\mathrm{AA}^{\prime}$ 断面 では, 打もに山梨県の道志下方, 深さ $20 \mathrm{~km}$ 前後から西 側に分布する震源域, およびより深い WB 西側の震源の かたまりが顕著である， $\mathrm{BB}^{\prime}$ 断面でも，WB を境に震源 分布の特徴が異なり, WB からその西側約 $9 \mathrm{~km}$ 位まで は深さ約 17〜25 km に震源が集中している．WB の東 側では深さ $15 \mathrm{~km} く ら い か ら \mathrm{~B}^{\prime}$ 方向（東北東）に深く なって傾く震源の並びがみられる。なお， $\mathrm{BB}^{\prime}$ 断面の西 側延長に位置する火山フロント沿いの富士山の下では, 
1 Apr. 1984 - 30 Sep. 1990

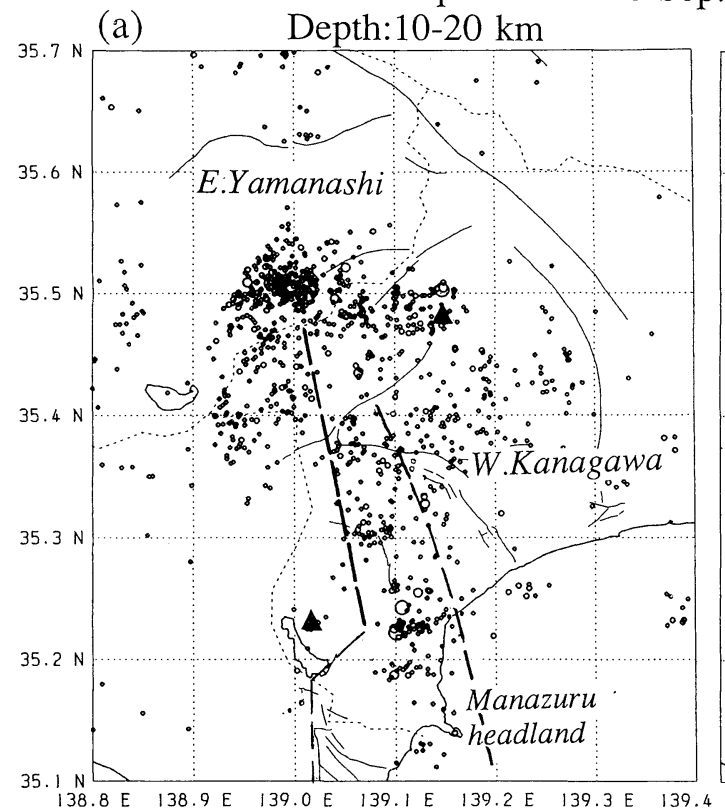

(b) Depth:20-30 km

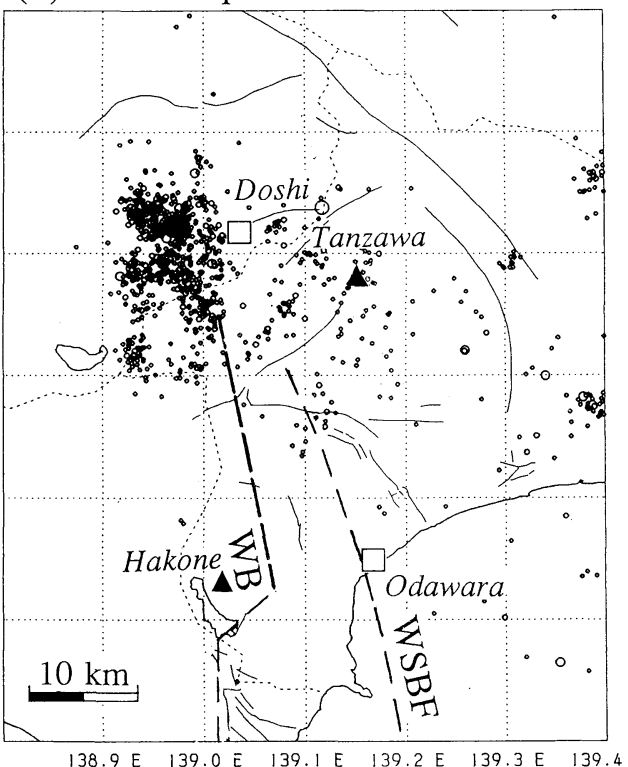

Fig. 3. Epicentral distribution of earthquakes during the period from April 1, 1984 through September 30,1990 , for $10 \leqq$ depth $<20 \mathrm{~km}$ (a) and $20 \leqq$ depth $<30 \mathrm{~km}$ (b). The thick broken line segment (abbreviated as WB) shows the surface projection of the vertical fracture in the Philippine Sea plate proposed by Yoshida (1990). In Figure (a) the western margin of the high-seismicity area in W. Kanagawa corresponds to the fracture boundary WB. Most earthquakes with $20 \leqq$ depth $<30 \mathrm{~km}$ in E. Yamanashi are concentrated on the west side of the northern extension of the WB. The broken curve WSBF indicates the surface projection of the upper edge of the West-Sagami-Bay fracture proposed by IsHiBASHI (1988a, b). Solid lines show major traces of active faults.

1 Apr. 1984 - 30 Sep. 1990 depth $\leq 35 \mathrm{~km}$

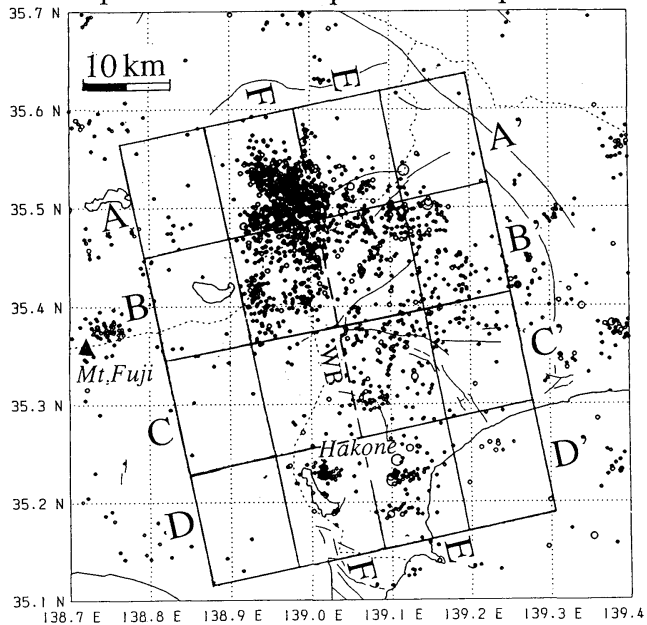

Fig. 4(a). Epicentral distribution of earthquakes with depth $\leqq 35 \mathrm{~km}$. Rectangular areas $\mathrm{A}-\mathrm{A}^{\prime}$ to $\mathrm{D}-\mathrm{D}^{\prime}\left(\mathrm{E}-\mathrm{E}^{\prime}\right.$ and $\left.\mathrm{F}-\mathrm{F}^{\prime}\right)$ correspond to the cross sectional areas shown in Fig. 4(b) (Fig. 4(c)). Solid lines show major traces of active faults.
深さ 10 数 $\mathrm{km}$ に地震活動がある.

次に, Fig. 4(b) の CC'断面において, WB の西側は, $\mathrm{AA}^{\prime}, \mathrm{BB}^{\prime}$ 断面之は対照的に地震活動が極めて低い.WB 東側の震源は, 深さ $10 \sim 20$ 数 $\mathrm{km}$ の範囲にあり, 全体 として $\mathrm{C}^{\prime}$ 方向（東北東）に傾く分布の特徴が見られる. さらに, $\mathrm{DD}^{\prime}$ 断面でも，WB の西側は $\mathrm{AA}^{\prime}, \mathrm{BB}^{\prime}$ 断面と 対照的に 10 数 $\mathrm{km}$ 以深の地震はほとんどみられず，火 山フロント沿いの箱根の下の浅い地震のみである.WB からその東側の小田原付近までは, 深さ $15 \mathrm{~km}$ 前後に 震源が集中し，それより浅い部分に地震がみられない。 この小田原の下の薄い震源分布は, その北側の $\mathrm{BB}^{\prime}$ や $\mathrm{CC}^{\prime}$ 断面では震源が深さ方向に $10 \mathrm{~km}$ 程度の厚さを持 つことと比べると特徵的である.

Fig. 4(b) の断面 $\mathrm{CC}^{\prime}$ と $\mathrm{DD}^{\prime}$ の東側半分の震源分布が 吉田 (1990)による 道志一小田原サイスミックゾーン’ を示し, その西端の形状は, 吉田 (1990) のように, 第一 近似としてほぼ鉛直な面と見なしても差し支えない，ま た，WSBF．の上端に対応する位置 $\left(\mathrm{CC}^{\prime}\right.$ 断面では WB の 東約 6〜 7 km, DD' では小田原の下付近）の東西で震源 の深さ分布に著しいくい違いはみられず，むしろ全体と 


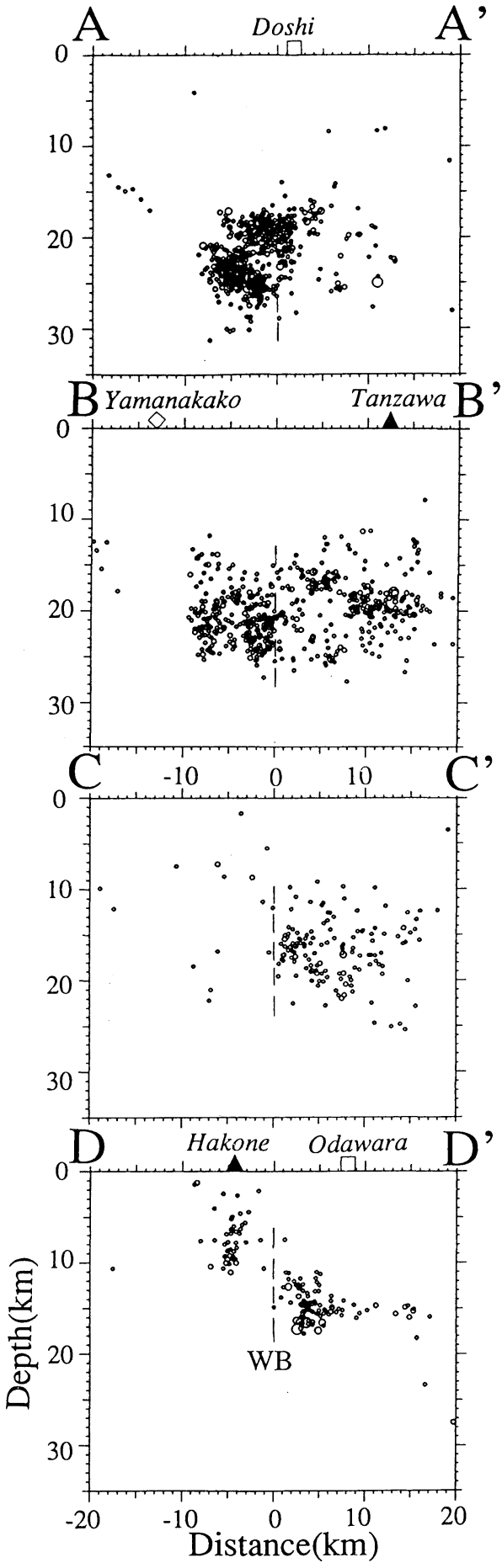

Fig. 4(b). Vertical cross sections of the hypocenters located within the rectangular areas $\mathrm{A}-\mathrm{A}^{\prime}$ to $\mathrm{D}-\mathrm{D}^{\prime}$ in Fig. 4(a). The vertical broken line shows the location of the WB.
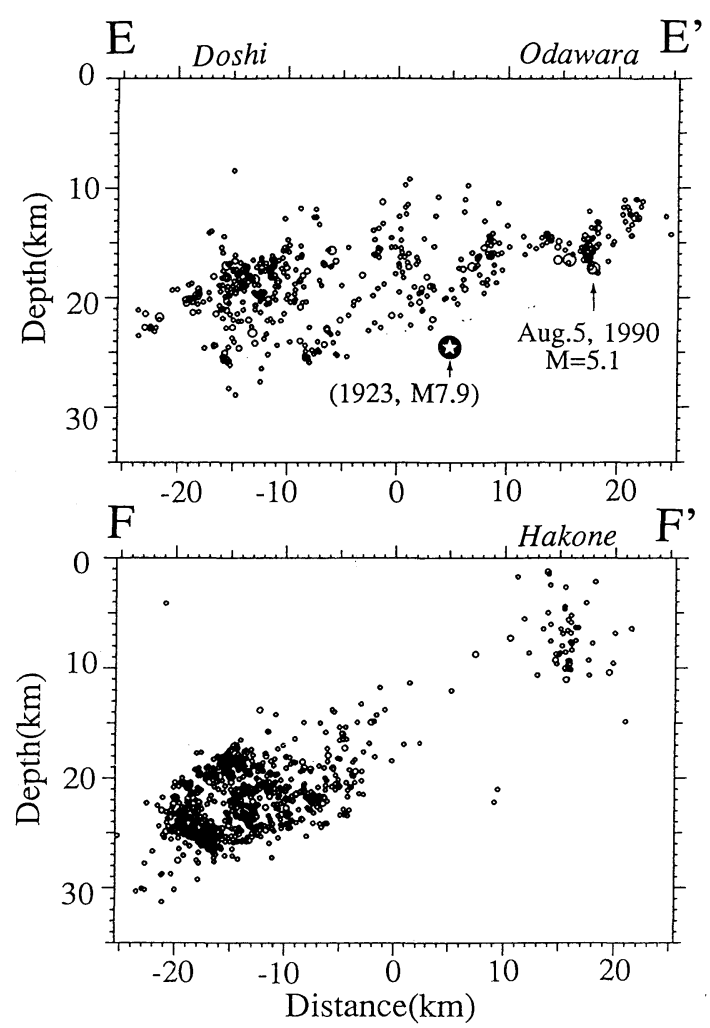

Fig. 4(c). Vertical cross sections of the hypocenters within the rectangular areas $\mathrm{E}-\mathrm{E}^{\prime}$ and $\mathrm{F}-\mathrm{F}^{\prime}$ in Fig. 4(a). The foci of the 1923 Kanto earthquake ( $M 7.9)$ [after HamadA (1987)] and the August 5, 1990 earthquake ( $M$ 5.1) are shown in the $\mathrm{E}-\mathrm{E}^{\prime}$ section.

して東北東へ傾斜する形状を示している.

Fig. 4(c) は, Fig. 4(a) の $\mathrm{EE}^{\prime}$ と $\mathrm{FF}^{\prime}$ 領域（各々幅 10 $\mathrm{km})$ の震源をWB に平行な北北西一南南東方向の鉛直 断面でみたものである. WB 東側の $\mathrm{EE}^{\prime}$ 領域のうち，深 さ約 10〜20 km の地震が “道志一小田原サイスミッ ク・ゾーン’ に対応している [Fig. 3(a) 参照]. また WSBF の位置も $\mathrm{EE}^{\prime}$ 断面に含まれている. この $\mathrm{EE}^{\prime}$ 断 面の震源分布の下端部に着目すると, 小田原付近の深さ $15 \mathrm{~km}$ 前後から山梨側の 26〜27 km 位まで全体として 勾配約 $20^{\circ}$ の傾斜した並びが認められる。 また，山梨県 側のより浅い $20 \mathrm{~km}$ 前後には, 別の傾斜した震源密集 域がみられるが，これを南側（ $\mathrm{E}^{\prime}$ 方向）の浅部に延長す ると, 小田原の下では浅い地震を欠くようにみえる [Fig. 4(b) の DD' 断面参照]. 1990 年 8 月 5 日に発生し た $M 5.1$ の地震は, 図中のように深さ $17 \mathrm{~km}$ に位置す る.また, 浜田 (1987) により再検討された 1923 年関東 地震 $(M 7.9)$ の震源位置（深さ $25 \mathrm{~km}$ ) あ示してある.

Fig. 4(c) の $\mathrm{FF}^{\prime}$ 断面では, 南部 ( $\mathrm{F}^{\prime}$ 側) の地震はほと 
1 Jan. 1980 - 30 Sep. 1990, 10-30 km

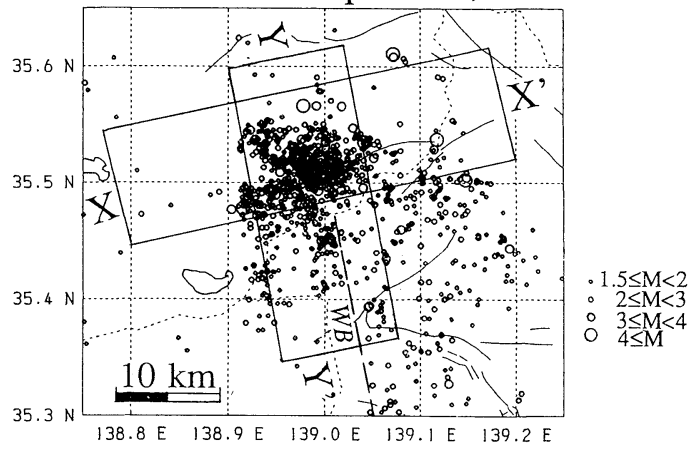

Fig. 5(a). Epicentral distribution of earthquakes with $10 \leqq$ depth $\leqq 30 \mathrm{~km}$ and $M \geqq 1.5$. Rectangular areas $\mathrm{X}-\mathrm{X}^{\prime}$ and $\mathrm{Y}-\mathrm{Y}^{\prime}$ correspond to cross sectional areas shown in Fig. 5 (b).

んど箱根の約 $10 \mathrm{~km}$ 以浅の地震のみである. 山梨県東 部の定常的活動を代表する $\mathrm{F}$ 側の震源集中域は深さ 17 〜 $27 \mathrm{~km}$ にあり, 上部の無震域との境界が明瞭である. この断面方向でみて, 震源域上端部は深さ $22 \mathrm{~km}$ 位ま では勾配 $30^{\circ}$ 前後の直線的形状を示し, $22 \mathrm{~km}$ 以深で は, より勾配が急で先端部が狭まる特徴を示している.

以上のように, 山梨県東部〜神奈川県西部の地震につ いて，WB 基準にすると，その東西て震源分布に顕著 な対照性がみられ，山梨県東部の主要な活動はWB の西 側に, 神奈川県西部の活動域はWB の東側に位置する. いま, WB を関東スラブと伊豆地塊の境界とすると, Fig. 4(c) の $\mathrm{EE}^{\prime}$ 断面では, 関東スラブ上面が伊東南東 沖付近の海底から山梨県側の深さ $20 \mathrm{~km}$ 前後まで滑ら かにあぐり込む構造が考えられる. 一方, Fig. 4(c) の $\mathrm{FF}^{\prime}$ 断面において，伊豆内弧の沈み込み口を石橋 $(1988$ a, b) のように箱根火山北方に置くと, WB 西側のスラブ は山梨東部の震源密集域に高角度でもぐり込み, その上 面の形状は WB 東側の関東スラブ上面の形状とは著し く異なる.この地域周辺のスラブの形状については, $\S 4$ で議論する.

\section{§3. 地震活動の時間変化と空白部の形成}

次に, 山梨県東部の地震活動について, Fig. 5(a)のよ うな WB を含む矩形域 $Y Y$ および WB に直交する矩 形域 $\mathrm{XX}^{\prime}$ をとり, Fig. 5(b) の (I) ( V) のように震源鉛 直分布の時間变化を調べる. 対象とする地震は, 1980 年 1 月 1 日〜 1990 年 9 月 30 日の $M \geqq 1.5$, 深さ 10 $30 \mathrm{~km}$ である.

まず，Fig. 5(b) の (I), (II) はそれぞれ 1980 年 1 月 1 日〜 1983 年 8 月 7 日，拈よび 1983 年 8 月 8 日〜 8 月
末の分布である. $\mathrm{XX}^{\prime}$ 断面の鉛直の破線が, $\mathrm{WB}$ を $\mathrm{XX}^{\prime}$ 領域に延長した線を表わす. (II) の期間の多くは 1983 年 8 月 8 日 12 時 48 分 (JST) に発生した $M 6.0$ とその 余震で，ほぼ $18 \sim 21 \mathrm{~km}$ の深さに位置する．XX'でみ ると, 震源域は主にWB 付近からその東側に約 $6 \sim 7$ $\mathrm{km}$ に渡って広がり, 本震はその東端に位置していて, 井元・他 (1984) の結果と調和する．また，YY'断面で みると，全体としてY 方向 (北北西)に緩く傾斜した分 布形状を示している. 前後の期間の地震の多くが WB の 西側に分布しているのに対し，この 1983 年 8 月の地震 はWB 近傍から東側の比較的浅い深さ $20 \mathrm{~km}$ 前後の破 壊であることがひとつの特徴である.

次に, Fig. 5(b) の (III) は, 1983 年 9 月 1 日〜1988 年 9 月 4 日まで約 5 年間の震源分布である. 先の 1983 年 8 月の地震の余震域での活動の他に, $\mathrm{XX}^{\prime}$ 断面では WB 西側の深さ $20 \sim 25 \mathrm{~km}$ にも集中域が見られる. YY' 断面では，全体に北北西に傾斜した分布を示し， 1983 年 8 月の地震の余震域はその上面に沿っているよ うに見える. また，この期間，WB西側の深さ $21 \sim 27$ $\mathrm{km}$ 位に周囲に比へ地震活動がきわめて低い領域がある ことに気が付く。このうち破線で示した棈円域に，次に 述べる $M 5.6$ の地震が発生した。

Fig. 5(b) の (IV) は, 1988 年 9 月 5 日〜9 月末までを 示し, ほとんどが 1988 年 9 月 5 日 00 時 49 分の $M 5.6$ とその余震である.これらは WB 延長面の西側の深さ約 24 27 km に位置し, 前述のようにそこはそれまで活 動がほとんどない空白域であった. Fig. 5(b) の (V) は, その後 1988 年 10 月から最近 1990 年 9 月末までの震 源分布である。括もに $20 \mathrm{~km}$ 以浅と 1988 年 9 月 5 日 の $M 5.6$ の震源域 （実線の楕円）で活発な活動が見ら れ，これらの震源域に挟まれた深さ $21 〜 24 \mathrm{~km}$ の領域 （破線の楕円）は依然として空白状態を示している.

Fig. 5 の震源分布と地震活動の特徵から, 次に, 深さ 範囲を 17〜21 km, 21〜24 km および 24〜27 km の 3 つに分けて，各薄層の震央分布を時間順に示すと Fig. 6 のようになる. 前述のように, 1983 年 8 月の地震は, お 屯に 17 21 km の深さに打いて，WB の北側延長線付 近からその東側に位置している. しかし，これ以外の活 動は，おもにWB 延長線の西側にあり，震源が深くなる ほどWB 延長の走向よりも西側にふれて配列する傾向 がみられる。

Fig. 6 の主要な活動域の時間変化をより詳しくみるた め, $35.5^{\circ} \mathrm{N}, 139.0^{\circ} \mathrm{E}$ を中心, 緯度, 経度各々 $0.05^{\circ}$ 毎 （約 $5.5 \mathrm{~km} \times 4.5 \mathrm{~km}$ ） の 8 個の小領域 A $\mathrm{H}$ に分割し, さらに上記 3 つの樑さ範囲に分けて $M \geqq 1.5$ の地震の積 算回数变化を調べた (Fig. 7). Fig. 7 の各積算曲線の变化 

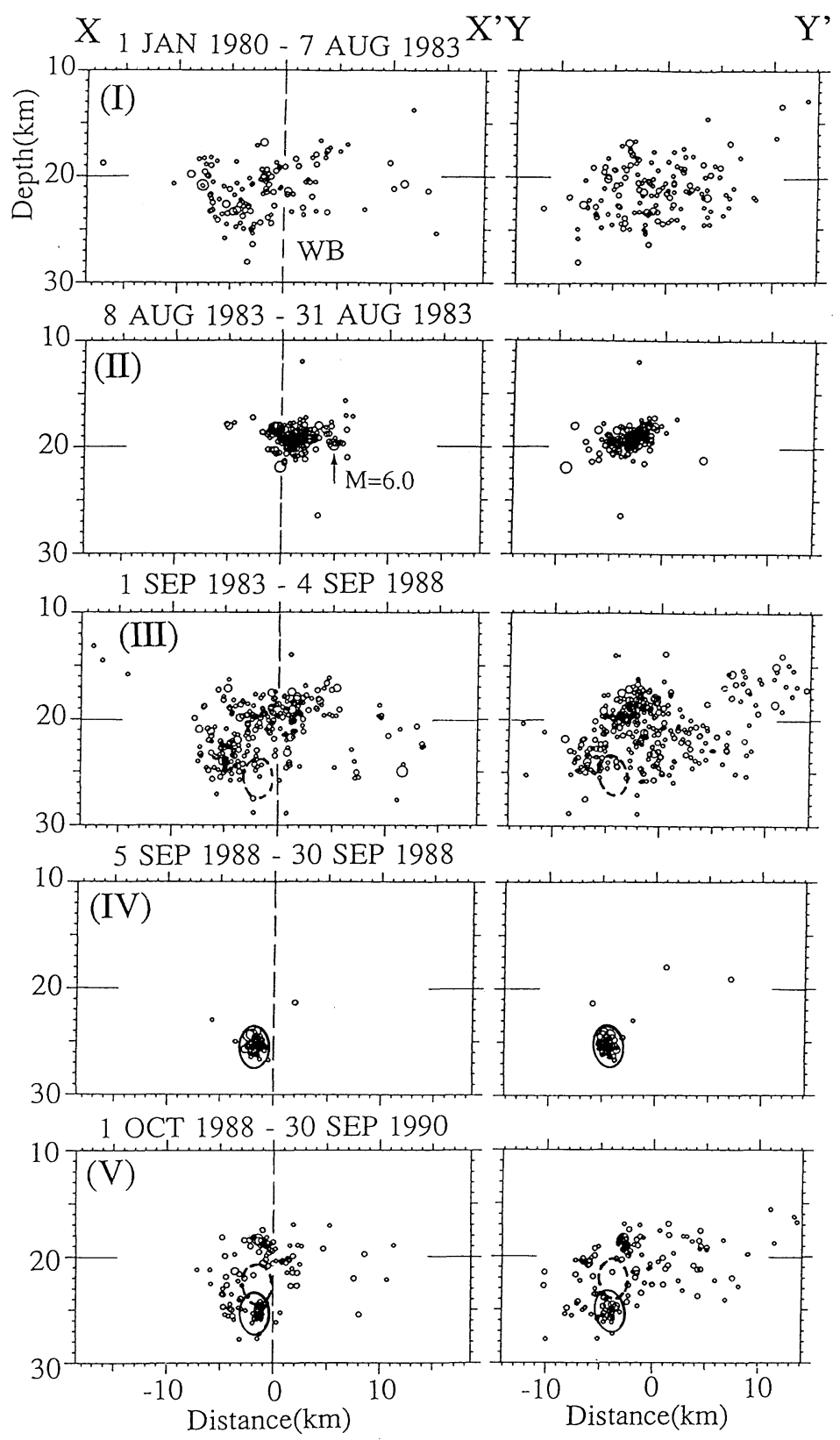

Fig. 5(b). Temporal variation of hypocentral distribution with $M \geqq 1.5$ in the cross sectional areas $\mathrm{X}-\mathrm{X}^{\prime}$ and $\mathrm{Y}-\mathrm{Y}^{\prime}$ for the period from January 1, 1980 through September 30, 1990. The vertical broken line in $\mathrm{X}-\mathrm{X}^{\prime}$ shows the location of the northward extension of the WB. Section II (August 8-31, 1983) shows that the August 8, 1983 earthquake with an $M 6.0$ and its aftershocks are distributed at relatively shallow depths around $20 \mathrm{~km}$, mostly nearby and to the east of the WB. The latest section $\mathrm{V}$ (October 1, 1988-September 30,1990) shows a small seismic gap just west of the WB at a depth range $21-24 \mathrm{~km}$, as encircled by the broken curve.

から，以下のような特徴が挙げられる（番号は, Fig. 7 に対応する).

（1）全期間を通して最も大きな 1983 年 8 月 8 日の
$M 6.0$ の地震の余震活動は, 主に深さ $17 \sim 21 \mathrm{~km}$ の B 域と C 域にまたがり，一部は南側の $\mathrm{F}$ と $\mathrm{G}$, 東側の D と H にも拡大している (Fig. 6). WB 東側の C 域の余震 

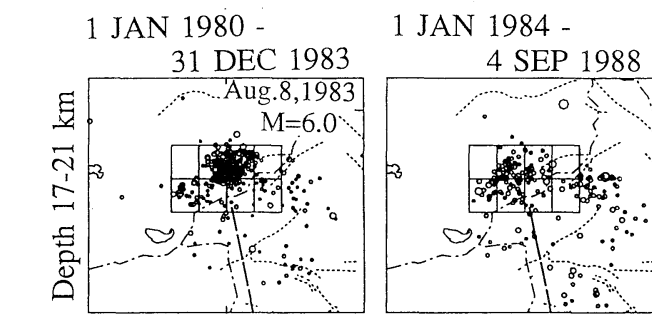

5 SEP 1988 -

1 OCT $1988-$
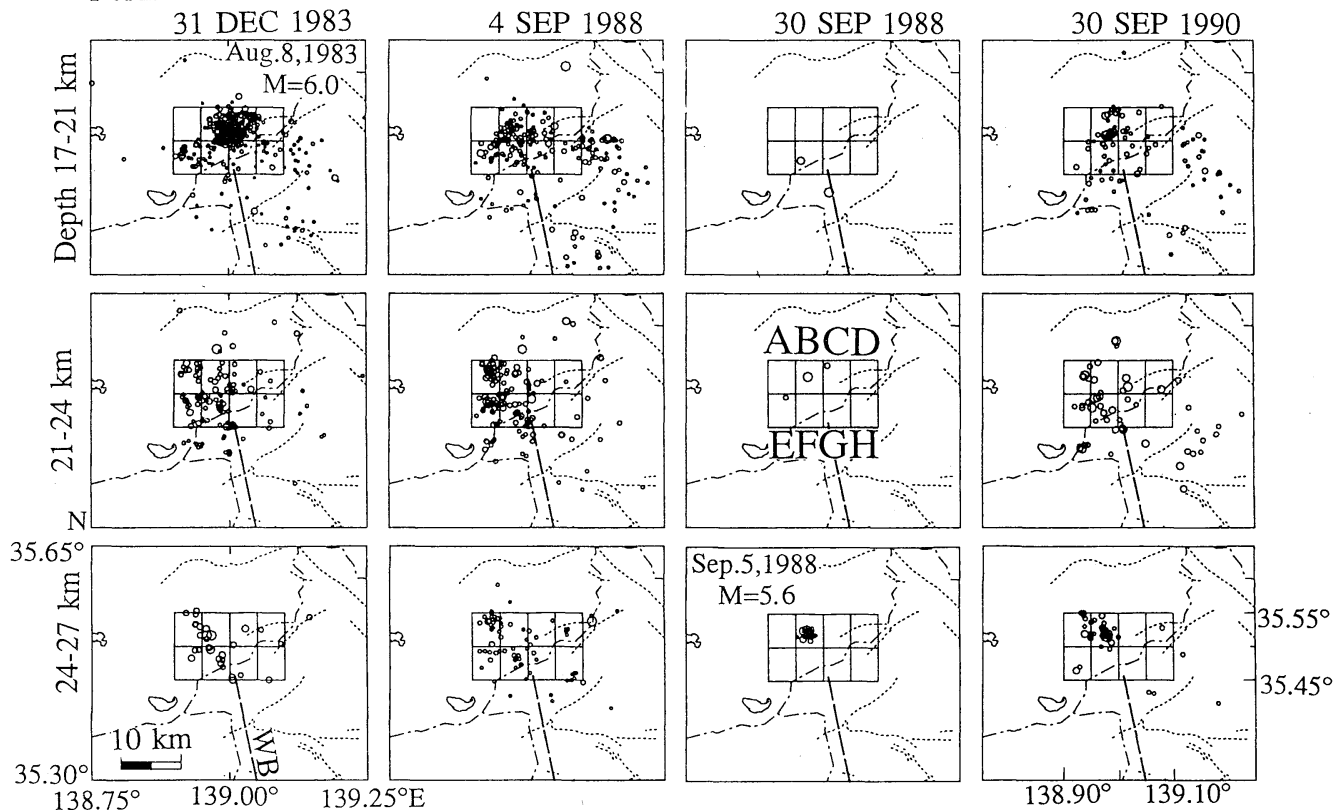

Fig. 6. Changes in seismicity with $M \geqq 1.5$ and in the depth ranges $17-21,21-24$ and $24-27 \mathrm{~km}$, respectively. Cumulative number of earthquakes within the small blocks A to $\mathrm{H}$ are shown in Fig. 7 .

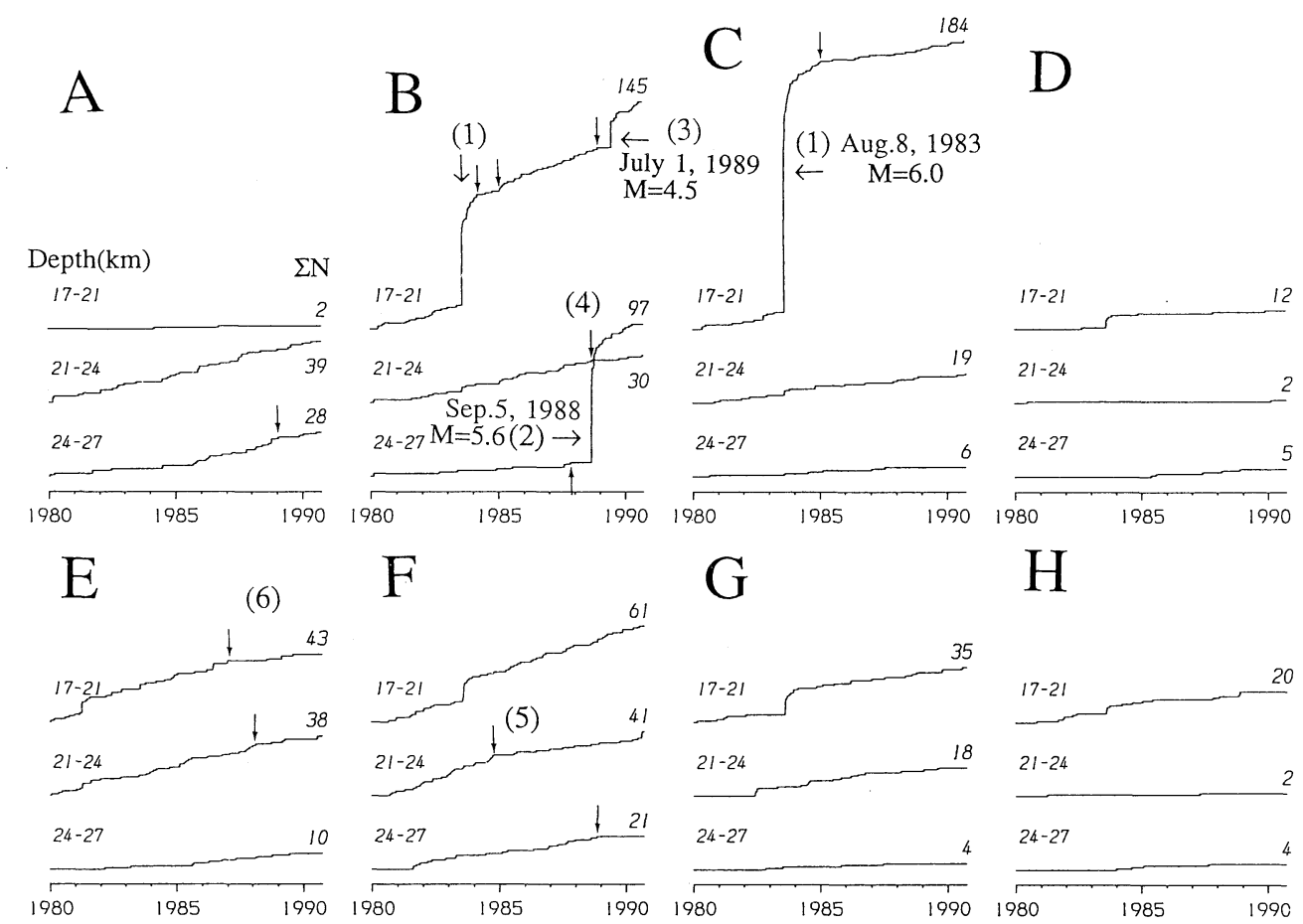

Fig. 7. Cumulative number of earthquakes with $M \geqq 1.5$ and depth ranges $17-21,21-24$ and $24-27 \mathrm{~km}$ in each block shown in Fig. 6 for the period from January 1, 1980 through September 30, 1990. The arrows indicate times of remarkable changes in seismicity. Refer to the text for the details of (1) to (6). 
活動は 1985 年 1 月下旬に終息し, この間 1983 年 8 月 8 日からの 160 個を除くと，C 域の定常的活動は高くな い. 西側の B 域の余震活動は 1984 年 3 月頃に収まった が，C 域と対照的に 1985 年 1 月末から再び活発化傾向 を示している. また, A 域, B 域の深さ $21 \mathrm{~km}$ 以深の地 震活動は, 1983 年 8 月の $M 6.0$ の地震の後, いくぶん 増大したようにみえる.

(2) 2 番目に大きな 1988 年 9 月 5 日の $M 5.6$ とそ の余震は, B 域の深さ $24 \sim 27 \mathrm{~km}$ で発生し, 以後 1990 年 4 月まで活発である. しかし，この地震前の 1980 年 初めから約 8 年 8 力月間は活動が低く, $M \geqq 1.5$ の数は 9 個で, その最後の地震は 1987 年 10 月 29 日の $M 2.0$ であった。

(3) 3 番目に大きな 1989 年 7 月 1 日の $M 4.5$ の地 震は B 域の深さ $17 \sim 21 \mathrm{~km}$ に発生した。この地震前の 1988 年 12 月から半年間 $M \geqq 1.5$ の地震のない期間が 継続した.

(4) B 域の深さ 21 24 km では, その上下の領域で (1), (2), (3) が発生したにも関わらず, 全期間を通して活 動は低く $M \geqq 1.5$ の地震総数は 30 個である. 詳しくみ ると, この領域の下側で発生した 1988 年 9 月 5 日の $M$ 5.6 の地震前後を境に，さらに一層活動が低下した傾向 が認められる.

(5) 南側 F 域の深さ $21 \sim 24 \mathrm{~km}$ では, 1984 年 9 月 末に積算回数の变化に顕著な折れ曲がりがみられ, これ 以後 1990 年 7 月末までの $M \geqq 1.5$ の地震の単位時間あ たりの発生回数は, それ以前の半分以下に減少した。 そ の後, 1990 年 8 月 19 日にこの領域としては珍しく $M$ 3.1 を含む 3 個の地震が発生した. また, F 域の $24 \sim 27$ $\mathrm{km}$ では, 1988 年 11 月 3 日の $M 1.7$ の地震以後 1990 年 9 月末現在まで活動がみられない.

(6) また $\mathrm{F}$ 域の西側の $\mathrm{E}$ 域の深さ $17 \sim 21 \mathrm{~km}$ およ び 21〜24 km, 北側 A 域の深さ 24〜27 km において あ, $M \geqq 1.5$ の地震は各々 1987 年 1 月以降, 1988 年 2 月以降および 1989 年 1 月以降減少傾向を示している.

以上, 山梨県東部の $M \geqq 1.5$ の地震活動を小領域に分 けやや細かく調べると, 領域毎に興味深い特徵がみられ た. 特に 1983 年 8 月 8 日の $M 6.0$ の発生と関連して, $\mathrm{B}$ 域周辺，すなわちほぼ $35.5^{\circ} \mathrm{N}, 139.0^{\circ} \mathrm{E}$ の北西側の 4 $\mathrm{km} \times 5 \mathrm{~km}$ 程度の広がりを持つ深さ $17 \sim 27 \mathrm{~km}$ の領域 と周辺の地震活動の時間変化が注目される. とりわけ, B 域の深さ $21 \sim 24 \mathrm{~km}$ の体積にして $3 \times 4 \times 6 \mathrm{~km}^{3}$ 位の 領域は, その上下領域での顕著な活動とは対照的に地震 活動が極めて低く, 現在空白域の様相を示している [Fig. 5(b) の最近の断面図参照]. また, B 域の西側〜南 西〜南側, すなわち WB 境界延長の西側のいくつかの領
域でも最近地震活動が系統的に低下する傾向が見られ る.

\section{§4. 考察・議論}

まず, 前節の山梨県東部の空白部について, 周辺の地 震活動の推移と合わせて考えると, MOGI (1979) による 第 1 種の空白域であり，かつまた第 2 種静穏化域とも見 ることができる.すなわち，その上下領域では，最近顕 著な地震が発生してそれらの余震活動で空白がほぼ埋 まったのに対して，そこは未破壊域のまま残っており， かつ近年地震活動の非常に低い状態が続いている．前述 のように, 1988 年 9 月 5 日の $M 5.6$ の地震によって, それまで存在していた空白域の約半分が埋まっており, 現在残っている空白域に今後も応力集中が進めば，そこ に $M 5 \sim 6$ 級程度の地震が発生しておかしくはない。

次に, 神奈川県西部から山梨県東部にかけての地震活 動にみられるWB とその北方延長線を境とした顕著な 対照性について，そのテクトニックな意味を考えてみ る. 石橋 $(1988 \mathrm{a}, \mathrm{b})$ は ‘西相模湾断裂” の性格について, 衝突している伊豆ブロックと, PHS プレートとともに $\mathrm{N} 30^{\circ} \mathrm{W}$ 方向 [石橋 (1984)］に沈み込む関東スラブとの 相対的な動きを解消するための PHS プレート内の裂け 目であるとしている.WB 両側での地震活動の顕著な対 照性は, WBがこの断裂境界面に対応することを強く示 唆する. しかし，WBの東側で地震面は北北東〜北東方 向に次第に深くなっており [例えば, Fig. 4(b)], WB の ところで東側の関東スラブが西側の伊豆地塊の下に沈み 込むとするのは無理がある. 吉田 (1990)のように, 関東 スラブのあぐり込みによる伊豆ブロックの西方への短縮 変動はない, すなわち関東スラブと伊豆ブロック間の相 対運動べクトルはそれらの境界面上にあると仮定し, 関 東スラブの沈み込み角度を $30^{\circ}$, 関東スラブと伊豆ブ ロックの相対運動方向を $\mathrm{N} 30^{\circ} \mathrm{W}, \mathrm{WB}$ の走向を $\mathrm{N} 10^{\circ}$ $\mathrm{W}$ として計算すると, WB は西下がりに約 $60^{\circ}$ 傾くこと になる.しかし, 実際には, WBを横断する Fig. 4(b) や 吉田 (1990) の震源分布断面のように, WB は第一近似 的にほとんど鉛直とみなせるから, 背理法的にいって関 東スラブと伊豆ブロックの相対運動方向は $\mathrm{N} 30^{\circ} \mathrm{W} よ$ りあ北向きであると考えられる．例えば，その相対運動 方向が WB の走向と同じであれば, WB 面は鉛直であっ てかまわない.

また, WB 付近での発震機構解から求めた $\mathrm{P}$ 軸の方位 分布は, ほぼ北西一南東方向であり [例えば, 鈴木 (1989)], 上で推定したWB 面での相対運動方向と矛盾 しない. また, 鈴木 (1989) は, 1980～1985 年の山梨県 東部の多数の地震（ただし, 1983 年 8 月 8 日〜 17 日を 
除く）の $\mathrm{P}$ 軸方位について, $139^{\circ} \mathrm{E}$ より東側の平均方位 は約 $\mathrm{N} 40^{\circ} \mathrm{W}$ ，西側では約 $\mathrm{N} 60^{\circ} \mathrm{W}$ としている，吉田・ 望月 (1986) は, 山梨県東部の地震は, 横ずれ型と逆断層 型の二種類に分類され，P 軸の向きがふたつの型で系統 的に異なり, 逆断層型の $\mathrm{P}$ 軸はより東西に近いとしてい る. 注目されることは, 彼らの示した横ずれ型と逆断層 型の震央分布のうち, 横ずれ型のほとんどが $139^{\circ} \mathrm{E}$ 以 東の WB 延長線よりも東側に, 逆断層型の半数以上が WB 付近とその西側に位置することである.これらのこ とは, 山梨県東部ではほぼ WB 延長線付近を境にして, 西側では東側に比べより東西方向の圧縮力を持つことを 示している: なお, 鈴木 (1989) は, 山梨県東部〜神奈川 県西部にかけては, 真鶴岬北西から道志村東方へ向かう WB よりやや南北に近い線を境に, 西側の $\mathrm{P}$ 軸が東側に 比べ系統的により東西方向に偏向するとしている.

1983 年 8 月 8 日の山梨県東部の $M 6.0$ の地震とその 余震は, 前述のようにWB 付近とその東側約 $6 \sim 7 \mathrm{~km}$ の, 深さ $20 \mathrm{~km}$ 前後という比較的浅部に発生したこと が大きな特徵である. 井元・他 (1984) によれば, 本震の 発震機構は横ずれ型で, $\mathrm{P}$ 軸はほぼ北西一南東である が，ふたつの節面の走向のいずれも余震分布と一致しな い. また, 余震は横ずれ型と逆断層型が混在し, 応力場 と媒質の複雜性を示唆するが, 余震は $\S 2,3$ でみたよう に, 北側にゆるやかに傾斜して分布する. また, 古川・ 井元 (1986) によると, 山梨県東部の $20 \mathrm{~km}$ 以浅の $\mathrm{P}$ 波 速度は, $6.1 \mathrm{~km} / \mathrm{sec}$ で上部地殼の花崗岩質層に対応す る. また, YosHIDA (1980)による海洋プレートの沈み込 みに伴う歪の蓄積過程と地震活動様式によると, 歪の蓄 積に積極的な役割を果たしているのは海洋プレートの運 動であり陸側プレートは受動的立場にあるが, 大地震発 生時はもっぱら陸側プレートが動き, 余震活動も陸側プ レート内で多く発生する.これらのことから, 著者達は, 1983 年 8 月の山梨県東部の地震は, 沈み込む関東スラ ブと陸側プレート間のカップリングに起因した主に陸側 プレート内の破壊現象であったと考える.

以上のような山梨県東部之神奈川県西部の震源分布之 地震活動の特徵, 吉田 (1990) が想定したWB の山梨県 東部への延長, および両地域を含む広範囲のいろいろな 方向の震源鉛直断面図を参照して，フィリピン海プレー 卜上面の等深度線を求めると Fig. 8 のようになる.これ は大局的な PHS プレート上面 [例えば, 野口 (1985), 石 田 (1989)］と調和するが，WBを境に PHS プレート上 面の走向・傾斜は異なり, WB 東側は関東スラブのもぐ り込み場, 西側は陸側プレートとの衝突域を表わしてい る.

Fig. 8 のプレート形状から, WB 東側に発生した

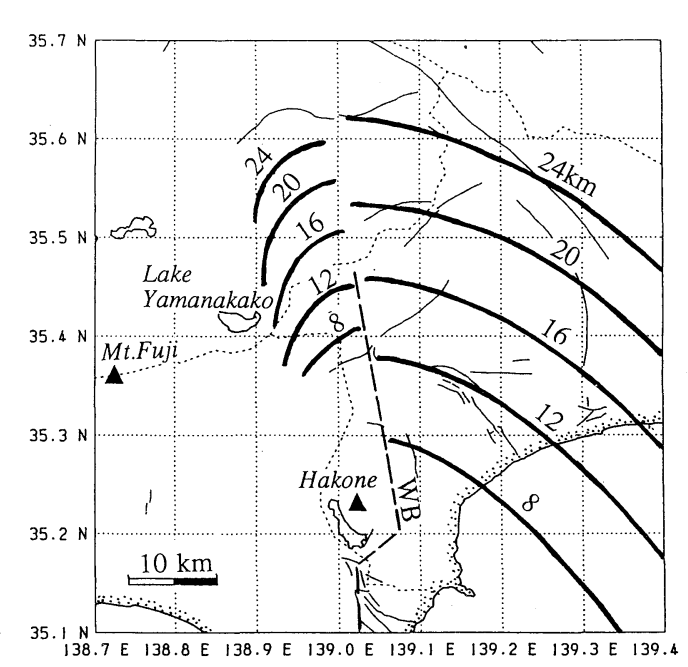

Fig. 8. Iso-depth contours of the upper plane of the Philippine Sea plate around the fracture boundary WB.

1983 年 8 月の $M 6.0$ の地震によって, 関東スラブの カップリングが変化し, それが WB 西側ブロック内の応 力場に影響を与えたことが推定される. 実際, 1983 年 8 月の地震発生後, WB 西側のいくつかの領域の定常的活 動が顕著に变化し (Fig. 7), 特に, WB 境界付近にある B 域 (Figs. 6,7) では, 深さ 17〜21 km および 24〜27 km での活発化およびその中間域での空白化傾向がみられ た. 地震活動が厚さ $3 \sim 4 \mathrm{~km}$ の領域ごとにそれぞれ増 大, 低下と変化したことは, この程度のスケールで媒質 の強度と凝着力が異なり, それぞれに固有の破壊・変形 運動をしたためと考えられる.

また, Fig. 8 および Fig. 4(c) の $\mathrm{EE}^{\prime}$ 断面から, 1990 年 8 月 5 日の $M 5.1$ はスラブ内の地震と推定される.こ の地震より浅部の小田原を中心とした地域は, 地震活動 のドーナッ・パターンの特徴を示している[例えば, 吉 田(1990)]. Fig. 8 と Fig. 4(c)の $\mathrm{EE}^{\prime}$ 断面によると,こ の空白域は，むぐり込む関東スラブの上面付近に対応す る. 神奈川県西部に繰り返される $M 7$ 級地震いわゆる 小田原地震の断層運動様式として, 左横ずれ型が推定さ れている [石橋 $(1988 \mathrm{a}, \mathrm{b})]$ が, プレート境界の低角逆断 層型となる可能性も否定できないのではなかろうか.

なお, 山梨県東部の震源域の西端, $138.9^{\circ} \mathrm{E}$ よりやや 東側においても， 82 で述べたように地震活動のない西 側との境界が明瞭である (例えば Fig. 1).このような震 源分布の特徵および地震波高速度層の解析から，この西 側に延長して PHS プレートを考えることは難しい［例 えば, 石田 (1990)].しかし, 变換波の観測から,この震 源密集域の西側や北西側の無震域にも速度不連続面が推 
定されている [涌井・北村 (1989), IIDAKA et al. (1990), 飯高・他 (1990)]。速度不連続面の実体と“見えないプ レート’ の存在の有無を明確にすることは, 山梨県東部 〜神奈川県西部の地震活動のテクトニックな意味, およ び関東地域のPHS スラブの範囲と形状 [例えば，岡田 (1990)によるレビュ一] を解明する上で不可欠なことで ある.

\section{§ 5. ま と め}

(1) 最近の微小地震データから, 神奈川県西部から山 梨県東部にかけて分布する深さ 10～ $20 \mathrm{~km}$ の地震帯の 西縁は, 吉田 (1990) が着目したように, 真鶴岬北西から 山梨県東部の震源密集域の東端部まで直線的に延び，ほ ぼ鉛直な境界面とみなせる、神奈川県西部の活動域はこ の境界面 (WB) の東側に, 山梨県東部の主要な活動域は その西側にあり，著しい対照性を示している.

(2)この WBをフィリピン海プレート内の断裂とす ると, WB 東側はフィリピン海スラブの関東下へのもぐ り込み場, WB 西側は浮揚性沈み込みをする伊豆地塊之 内陸プレートとの衝突場とみなせる. 1983 年 8 月 8 日 の $M 6.0$ の地震は, 関東下に沈み込むフィリピン海スラ ブと陸側プレートのカップリングに起因したプレート境 界とその上盤陸側プレート内での破壊現象と考えられ る.

(3) 1980 年 1 月 1 日〜 1990 年 9 月末までの，山梨 県東部の $M \geqq 1.5$ の地震の震源分布とその時間変化を領 域を区切って詳しくみると, $35.5^{\circ} \mathrm{N}, 139.0^{\circ} \mathrm{E}$ の北西側 (WB 西側) の深さ $21 \sim 24 \mathrm{~km}$ に, その周辺に比べて著 しく地震活動の低い空白域が認められる. また, WBの 南〜南西側のいくつかの小領域でも 1985 年前後から最 近にかけ地震活動が目だって低下する傾向がみられ，今 後の活動の推移が注目される.

（4）神奈川県西部の小田原を中心とした地域では, 1935 年以来 $M 5$ 以上の地震の発生を見ず, 1988 年初 めからは $M 2.5$ 以上の地震活動も顕著に低下していた [吉田 (1990)] が, 1990 年 8 月 5 日, WB 東側に $M 5.1$ の地震が発生した. 山梨県東部と神奈川県西部は, フィ リピン海プレート内の断裂を介してテクトニックに密接 な関係にあると考えられることから, 山梨県東部の地震 活動と合わせて神奈川県西部の地震活動についても注意 深く見ていく必要がある.

\section{謝辞}

防災科学技術研究所の松村正三氏, 岡田義光氏から は，地震データについて有益なご教示をいただきまし た. また, 建築研究所の石橋克彦氏および査読者からは,
草稿に関して有益かつ適切なご助言をいただきました。 ここに感謝の意を表します.

\section{文献}

浜田信生, 1987,1923 年関東地震の震源の深さについ て, 験震時報, 50, 1-6.

堀内茂木 - 河野俊夫 - 村上栄寿 - 仁田交市 - 松本 聡 長谷川 昭・高木章雄, 1989 , 沈み込んだフィリピン 海プレートの先端部付近からの反射波について, 地震 学会講演予稿集, No. 1, 69.

古川信雄・井元政二郎, 1986, 地震発生域の地震波速度 一山梨県東部地震一, 地震 $2,39,35-45$.

Iidaka, T., M. Mizoue, I. Nakamura, T. Tsukuda, K. Sakai, M. Kobayashi, T. Haneda and S. Hashimoto, 1990, The upper boundary of the Philippine Sea plate beneath the western Kanto region estimated from S-P-converted wave, Tectonophysic, 179, $321-326$.

飯高 隆 - 溝上 恵 - 中村 功 - 佃 為成 - 酒井 要 小林 勝・羽田敏夫・橋本信一, 1990, 伊豆半島北部 周辺のプレート境界近傍での変換波について, 地震学 会講演予稿集, No. 2, 153.

井元政二郎 - 島田誠一 - 岡田義光 - 笠原敬司 - 大竹政 和, 1984, 1983 年 8 月 8 日 山梨県東部の地震 $(M$ 6.0) とその前後の地震活動について, 国立防災科学技 術センター研究速報, 57 号, 1-13.

石橋克彦, 1977, 「西相模湾地震」の可能性と東海地震 との関連, 地震予知連絡会東海部会資料, 53-68.

石橋克彦, 1980 , 伊豆半島をめぐる現在のテクトニク ス, 月刊地球, 2, 110-119.

石橋克彦, 1984, 南部フォッサマグナ地域のプレート運 動一日本海沈み込み説の適用一, 月刊地球, 6,61-67.

IsHIBASHI, K., 1985, Possibility of a large earthquake near Odawara, Central Japan, preceding the Tokai earthquake, Earthq. Predict. Res., 3, 319-344.

石橋克彦, $1988 \mathrm{a}$, “神奈川県西部地震” と地震予知 I, 科 学, 58, 537-547.

石橋克彦, $1988 \mathrm{~b}$, “神奈川県西部地震” と地震予知 II, 科学, 58, 771-780.

石田瑞穂, 1989, フィリピン海プレート北端部でのプ レートの沈み込み その 2, 地震学会講演予稿集, No. $1,46$.

石田瑞穂, 1990, 関東・東海地域の地震活動とプレート 構造，地質二ュース，432 号，18-26.

笠原敬司，1985a，プレートが三重会合する関東・東海 地方の地壳活動様式, 国立防災科学技術センター研究 報告, 35 号, 33-137.

笠原敬司, $1985 \mathrm{~b}$, 関東南部における大地震再来周期に ついて, 月刊地球, 7, 440-445.

松村正三, 1985, 国立防災科学技術センターの地震力タ ログに含まれる発破データの識別, 地震 $2,38,457-$ 459.

Mogi, K., 1979, Two kinds of seismic gaps, Pure Appl. Geophys. 117, 1172-1186.

野口伸一, 1985, フィリピン海プレートの形状と茨城地 震活動の特徴, 月刊地球, 7, 97-104. 
野口伸一, 1990, 最大速度振幅の距離減衰の地域性と地 震のマグニチュード，国立防災科学技術センタ一研究 速報, 第 86 号, 1-40.

岡田義光, 1990, 南関東地域のサイスモテクトニクス, 地震 2, 43, 153-175.

Papanastassiou, D. and S. Matsumura, 1987, Examination of the NRCDP's (The National Research Center for Disaster Prevention) seismic observational network as regards I. Detectabilitylocatability II. Accuracy of the determination of earthquake source parameters, Rep. NRCDP, 39, $37-65$.

坂田正治, 1987, 小田原地震について, 防災科学技術, 61 号, 15-17.

鈴木宏芳, 1989 , 関東・中部地域の地殼内地震の発震機 構と地款応力場, 国立防災科学技術セン夕一研究報 告, $43,1-125$.

津村紀子・堀内茂木・長谷川 昭・笠原敬司, $1990, \mathrm{SP}$ 変換波による山梨県東部におけるフィリピン海プレー 卜の上部境界面の位置の推定, 地震学会講演予稿集,
No. 2, 204.

宇津徳治, 1979,1885 年 1925 年の日本の地震活動一 $M 6$ 以上の地震および被害地震の再調査一, 地震研彙 報, 54, 253-308.

涌井仙一郎・北村良江, 1989, 山梨・神奈川県境付近の 地震にるられる顕著な位相, 地震学会講演予稿集, No. 1,70 .

YoshidA, A., 1980, Antidislocation as a source of earthquake, Pap. Meteorol. Geophys., 31, 7-14.

吉田明夫, 1990 , 神奈川県西部の地震活動とその地学的 意味，地震 $2,43,205-212$.

吉田明夫・浜田信生, 1989,1931 年西埼玉地震の余震 活動及びその前後の周辺地域の地震活動, 地震学会講 演予稿集, No. 1, 149.

Yoshida, A. and N. HAMAdA, 1991, Redetermination of foreshocks, main shock and aftershocks of the Kita-Izu earthquake and the Ito earthquake swarm of 1930, J. Phys. Earth, 39, 329-344.

吉田明夫・望月英志, 1986 , 山梨県東部の地震の発震機 構, 地震学会講演予稿集, No. 2, 44 . 